\title{
Konstruksi Perayaan Imlek Pada Film Animasi Upin Dan Ipin Dalam Episode “ Gong Xi Fa Cai “ Di MNCTV
}

\author{
Rd. Dancu Lokita Pramesti Dewi \\ Institut Ilmu Sosial dan Manajemen STIAMI \\ Program Studi Manajemen Komunikasi - Fakultas Ilmu Sosial dan Manajemen \\ email : lokita_plokita@yahoo.com
}

Animation Film of Upin and Ipin is a LES COPAQOE production of Malaysian animation movie science and education movie for children. In Indonesia, 'Upin and Ipin' is broadcast in SCTV. This movie is not only suitable for children, but also for all ages. There are a lot of messages that we can absorb from this movie, such as family matter, friendship, and culture. This movie provides good lessons about social issues for its audience. The purpose of this research is to find out more about the characterizations of every cast, and the meaning of Imlek celebration in Upin and Ipin film. The film shows heterogeneous characters in every cast. This research takes an episode of Gong Xi Fa Cai in Upin and Ipin series. The film is attractive because it talks about the relationship of diversity.

Keywords:

Semiotics Analysis,

Roland Barthes

The meaning of Imlek Celebration in Upin and Ipin film is a spiritual celebration and Constructions, Celebration of Imlek the life core of Chinese people. The spiritual meaning of Imlek celebrations is not merely celebrated by Chinese people, but it is also celebrated by other tribes in this film. The film shows about sharing happiness in line with the meaning of Imlek namely the spirit and ability to share with others, help each other, and live in peace.

\section{PENDAHULUAN}

Interaksi antara dua negara berbeda dalam konteks geografis yang berdekatan, menjadi sesuatu yang tidak mudah untuk dihindari. Interaksi tersebut dapat terjadi dalam bentuk kooperatif maupun konflik. Interaksi antara kedua negara tidak hanya terjadi dalam konteks aparatur negara saja, namun juga dapat melibatkan warga negara yang bersangkutan. Semisal, interaksi dalam konteks sosial, kebudayaan, politik, ekonomi, dan budaya. Interaksi antar dua negara yang berdekatan secara geografis dapat dilihat di Negara Indonesia dan Malaysia. Interaksi yang terjadi dapat memunculkan salah satu negara menjadi dominan dan negara lain yang terdominasi. Kedekatan secara geografis antara Indonesia dan Malaysia, memungkinkan terjadinya interaksi dalam beberapa bidang, semisal bidang budaya. Bidang budaya titik persinggungan terkait dengan sisi historis, dimana Indonesia bagian Barat memiliki kemiripan dengan kebudayaan di perbatasan Malaysia.

Seiring dengan perkembangan media komunikasi massa yakni televisi, semakin banyak film kartun atau Film animasi dengan target khalayak anak-anak. Akan tetapi, isi pesan yang disampaikan dalam film dengan konten untuk anak-anak ada yang memberikan gambaran tentang kekerasan fisik, adegan perkelahian, yang tidak memberikan dampak baik bagi penontonnya. Ditengah terpaan acara televisi anak-anak yang gencar seperti sekarang ini, orang tua seharusnya menjadi pendamping anak-anak saat melihat acara televisi tersebut. Tanpa kehadiran orangtua dalam pendampingan anak-anak, dapat mengakibatkan anak-anak menangkap seluruh konten tanpa menyaring mana yang boleh dan tidak boleh ditiru.

Hasil produksi kedua negara pernah saling "mengekspansi", bahkan pernah terjadi pengakuan hasil budaya negara yang satu dengan negara lainnya. Pada satu era tertentu hasil budaya populer di Indonesia mengekspansi Malaysia, begitupun sebaliknya. Misalnya film produksi Malaysia yang terkenal di pertelevisian Indonesia di era 90 -an Syahdan, dan ada juga Film Indonesia yang meledak di pasaran Film di Malaysia seperti Ayat-ayat Cinta dan Ketika Cinta Bertasbih. 
Pada saat ini film produksi Malaysia yang sedang berjaya di pertelevisian Indonesia yaitu Film Animasi Upin dan Ipin. Film Animasi Upin dan Ipin pada awalnya ditayangkan di Televisi Pendidikan Indonesia (TPI) yang kini berubah menjadi MNCTV. Film animasi ${ }^{1}$ Upin dan Ipin merupakan salah satu tontonan yang disukai anak-anak. Acara ini ditayangkan guna menghibur penonton. Selain film animasi Upin dan Ipin, beberapa tayangan animasi karya Indonesia juga ditayangkan, seperti Adit Sopo \& Jarwo, Didi Tikus, Si Entong, dan Keluarga Somad.

Tayangan televisi untuk anak-anak tidak bisa dipisahkan dengan film animasi atau kartun. Jenis film animasi sangat populer dilingkungan anak-anak, bahkan tidak sedikit orang dewasa yang menyukai film animasi. Pada awalnya, film animasi memang dibuat sebagai sarana hiburan bagi anak-anak. Namun, perkembangan teknologi animasi dan industri film turut memperluas ruang gerak film kartun, baik dari segi tema, cerita maupun gambar, sehingga segmen penontonnya pun meluas.

Animasi merupakan suatu proses menggambar dengan memodifikasi gambar dari tiap-tiap frame yang diekspos pada tenggang waktu tertentu sehingga tercipta sebuah ilusi gambar bergerak. Animasi adalah menghidupkan gambar, sehingga perlu mengetahui dengan pasti setiap detail karakter, mulai dari tampak depan, belakang, samping, dan detail muka karakter dalam berbagai ekspresi. Dalam penelitian Ramadhani (2018) terlihat bagaimana animasi film Inside Out sebagai bagian dari media menjadi sarana komunikasi, dimana representasi emosi dalam film Inside Out tersaji melalui karakter, seperti emosi sedih, ikut menangis, jatuh cinta, kesal, gembira bahkan tertawa.

Seiring dengan berkembangnya media komunikasi massa yakni televisi, semakin banyak film kartun atau film animasi yang disiarkan di televisi untuk di tonton oleh anak-anak, mudah sekali untuk menonton sebuah tayangan tanpa adanya kontrol yang memadai, sehingga membuat televisi menyajikan banyak sekali pilihan yang sangat disukai oleh penonton khususnya anak- anak. Akan tetapi sajian atau isi pesan yang disampaikan dalam film tersebut ada juga yang banyak memberikan gambaran tentang kekerasan fisik, adegan perkelahian, yang tidak memberikan dampak baik bagi penontonnya, contohnya kartun Crayon Shincan, Detective Conan atau Naruto.

Hadirnya film animasi Upin dan Ipin memberi warna baru dalam pertelevisian, terutama tayangan untuk genre anak-anak. Film animasi Upin dan Ipin mengajarkan nilai-nilai positif, karena menyajikan bagaimana caranya menghormati agama lain, menghormati perbedaan budaya, perbedaan suku dan ras. Seperti contohnya dalam film Upin \& Ipin episode Gong Xi Fa Cai ${ }^{2}$, dimana Upin Ipin dan kawan-kawannya hadir ke undangan keluarga meimei (digambarkan sebagai seorang Tionghoa) dalam merayakan tahun baru imlek agama kepercayaan Tionghoa ${ }^{3}$.

2 Pengertian dari kata Gong Xi Fa Cai (dibaca: Kiong Hi Fat Chai) jika diartikan adalah "Selamat \& Sejahtera", merupakan ucapan yang biasa digunakan pada saat Imlek. Penggunaan dua kata pertama adalah "Gong Xi" memiliki sejarah penggunaan yang cukup panjang, tetapi jika berdasarkan legenda maka ucapan ini digunakan untuk mengucapkan selamat kepada penduduk cina yang telah mengatasi binatang buas Nian yang kerap memangsa mereka, namun diluar legenda pada kenyataan ini lebih pada ucapan selamat merayakan hari raya diantara para penduduk cina untuk merayakan juga berlalunya musim dingin yang luar biasa kerasnya. Pada perkembangan selanjutnya seiring membaiknya harapan kesejahteraan yang menggangkat kondisi yang serba keras. Semangat kapitalisme dan konsumerisme yang melanda seluruh komunitas china seluruh dunia menjadikan ditambahnya "Fa Chai" (sejahtera atau makmur) dalam kata tersebut.

${ }^{3}$ Tahun baru Imlek merupakan perayaan terpenting orang Tionghoa. Perayaan tahun baru Imlek dimulai dihari pertama bulan pertama dipenanggalan Tionghoa dan berakhir dengan Cap Go Meh ditanggal ke Limabelas (pada saat Bulan Purnama). Malam tahun baru Imlek dikenal sebagai Chuxi atau malam pergantian Tahun. Di China daratan, adat dan tradisi wilayah yang berkaitan dengan tahun baru imlek sangat beragam, namun hadir dengan berbagai tema umum seperti perjamuan makan malam besar (Tua Ciak Me) pada malam sehari sebelum tahun baru imlek, pesta atau penyulutan kembang api, silaturahmi kepada keluarga yang lebih tua atau senior, dan pembagian ang pao kepada anakanak, keluarga yang belum menikah dan fakir miskin. 
Berdasarkan pengamatan penulis, serial Upin dan Ipin episode Gong Xi Fa Cai memiliki nilai-nilai pendidikan dan nilai budi pekerti serta kerukunan antar budaya dan kerukunan antar umat beragama. Penulis memilih meneliti film animasi Upin \& Ipin episode Gong Xi Fa Cai karena film animasi Upin dan Ipin telah beberapa kali mendapatkan penghargaan ${ }^{4}$. Selain itu, film animasi Upin dan Ipin masih mempunyai keterikatan budaya dan bahasa yang tidak terlalu jauh dengan bangsa Indonesia, sehingga nilai-nilai akan lebih mudah diterima di Indonesia.

\section{KERANGKA TEORITIS}

Paradigma konstruktivis menurut Egon Guba dan Yvonna Lincoln adalah paradigma elektrik dalam banyak aspek. Dalam penjelasan ontologi paradigma konstruktivis, realitas merupakan konstruksi sosial yang diciptakan oleh individu. Namun demikian kebenaran suatu realitas sosial bersifat nisbi, yang berlaku sesuai konteks spesifik yang dinilai relevan oleh pelaku sosial. Paradigma konstruktivis merupakan anti-tesis atau bentuk perlawanan dari hegemoni paradigma positivis yang sangat mekanistik dan simplifistik. Aliran positivis memandang manusia diatur oleh alam (determinism), yang bersifat objektif dan menepikan nilai sarat kreativitas sebagai sesuatu yang inheren bahkan given dalam diri manusia.

Paradigma konstruktivis merupakan salah satu perspektif dalam tradisi sosiokultural, yang menyatakan bahwa identitas benda dihasilkan dari bagaimana individu berbicara tentang objek, bahasa yang digunakan untuk mengungkapkan konsep, dan cara-cara kelompok sosial menyesuaikan diri pada pengalaman umum mereka (Morissan, 2009: 107). Keberadaan simbol atau bahasa menjadi penting dalam proses pembentukan realitas. Selain itu, masyarakat adalah sesuatu yang kompleks yang terdiri dari relasi antar manusia yang relatif besar dan berpola (Samuel, 2012: 1). Berbagai kelompok dengan identitas, pemaknaan, kepentingan, pengalaman, dan sebagainya mencoba mengungkapkan diri dan selanjutnya akan memberikan sumbangan dalam membentuk realitas secara simbolik. Realitas secara simbolik merupakan hasil kesepakatan bersama secara sosial. Realitas tidak menunjukan dirinya dalam bentuknya yang kasar, tetapi harus disaring terlebih dahulu melalui bagaimana cara kita atau seseorang melihat sesuatu (Littlejohn dan Foss, 2011:67).

Asal usul konstruksi sosial dari filsafat konstruktivisme yang dimulai dari gagasan konstruktif kognitif. Menurut Von Glaserfeld, pengertian konstruktif kognitif muncul pada abad ini dalam tulisan Mark Baldwin yang secara luas diperdalam dan disebarkan oleh Jean Piaget. Sejauh ini ada tiga konstruktivisme, yaitu konstruktivisme radikal, realisme hipotesis, dan konstruktivisme biasa. Konstruktivisme Radikal hanya dapat mengakui apa yang dibentuk oleh fikiran kita, dimana bentuk itu tidak selalu menjadi representasi dunia nyata. Kaum konstruktivisme Radikal mengesampingkan hubungan antara pengetahuan dan kenyataan sebagai suatu kriteria kebenaran. Pengetahuan bagi mereka tidak merefleksikan suatu realitas ontologi obyektif, namun sebuah realitas yang dibentuk oleh pengalaman seseorang.

Dalam pandangan realisme hipotesis, pengetahuan adalah sebuah hipotesis dari struktur realitas yang mendekati realitas dan menuju kepada pengetahuan yang hakiki. Sedangkan konstruktivisme biasa mengambil semua konsekuensi konstruktivisme dan memahami pengetahuan sebagai gambaran dari realitas itu. Kemudian pengetahuan individu dipandang sebagai suatu gambaran yang dibentuk dari realitas objek dari dalam dirinya sendiri. Ketiga konstruktivisme tersebut memiliki persamaan, dimana konstruktivisme dilihat sebagi suatu kerja kognitif individu untuk menafsirkan dunia realitas yang ada karena terjadi relasi sosial antara individu dengan lingkungan atau orang disekitarnya. Individu kemudian membangun sendiri pengetahuan atas realitas yang dilihat itu berdasarkan pada struktur pengetahuan yang telah ada sebelumnya, yang oleh Piaget disebut sebagai skema. Pengetahuan selalu merupakan konstruksi dari individu yang mengetahui dan tidak dapat ditransfer kepada individu lain yang pasif. Karena itu konstruksi harus

\footnotetext{
${ }^{4}$ Upin dan Ipin dinobatkan dalam Malaysia Book of Records sebagai Animasi paling terkenal pada tahun 2011. Penghargaan pada tahun 2007 oleh Festival Film Antarbangsa Kualalumpur. Penghargaan pada tahun 2009 oleh Anugrah Shout dan tahun 2010 mendapat penghargaan oleh Indonesia Kids Choice Awards.
}

Rd. Dancu lokita Pramesti Dewi et al. (Konstruksi Perayaan Imlek Pada Film Animasi Upin Dan Ipin...) 
dilakukan sendiri olehnya terhadap pengetahuan itu, sedangkan lingkungan adalah sarana terjadinya konstruksi itu.

Berger dan Luckmann mengatakan institusi masyarakat tercipta dan dipertahankan atau diubah melalui tindakan dan interaksi manusia. Meskipun masyarakat dan institusi sosial terlihat nyata secara obyektif, namun pada kenyataan semuanya dibangun dalam definisi subyektif melalui proses interaksi. Objektivitas baru bisa terjadi melalui penegasan berulang-ulang oleh individu lain dengan definisi subyektif yang sama. Pada tingkat generalitas yang paling tinggi, manusia menciptakan dunia dalam makna simbolik yang universal, yaitu pandangan hidupnya yang menyeluruh, yang memberi legitimasi dan mengatur bentuk-bentuk sosial serta memberi makna pada berbagai bidang kehidupannya.

Sifat-sifat konstruktivis ada empat. Pertama, konstruksi adalah upaya untuk menjelaskan atau menafsirkan pengalaman dan kebanyakan bersifat bias. Mempertahankan dan memperbaharui diri. Kedua, sifat dan kualitas konstruksivis yang dihasilkan bergantung pada "rangkaian informasi yang tersedia bagi si konstruktor, dan kecanggihan konstruktor dalam mengolah informasi tersebut". Ketiga, konstruksi dikenal secara luas dan merupakan konstruksi yang diupayakan, dalam arti upaya-upaya kolektif dan sistematis demi sebuah kesepakatan umum tentang sesuatu misalnya ilmu pengetahuan. Keempat, meskipun semua konstruktivis harus dianggap bermakna sebagiannya bisa saja dianggap sebagai "malkonstruksi" karena tidak lengkap, simplistik, tidak menjelaskan secara internal inkonsisten atau diperoleh melalui sebuah metodologi yang tidak memadai. Dalam hal ini dapat dipahami bahwa dengan paradigma konstruktivis diharapkan peneliti dapat menemukan hal-hal yang diinterprestasikan oleh para penonton dari film animasi Upin dan Ipin dengan meneliti bagaimana penokohan film animasi Upin dan Ipin dikonstruksikan. Serta bagaimana konstruksi dari simbol-simbol atau makna-makna yang terdapat di film ini sehingga dapat menciptakan sebuah interprestasi pesan pada penonton yang mungkin saja dapat berbeda dari satu penonton dengan penonton yang lainnya.

\section{KERANGKA PEMIKIRAN}

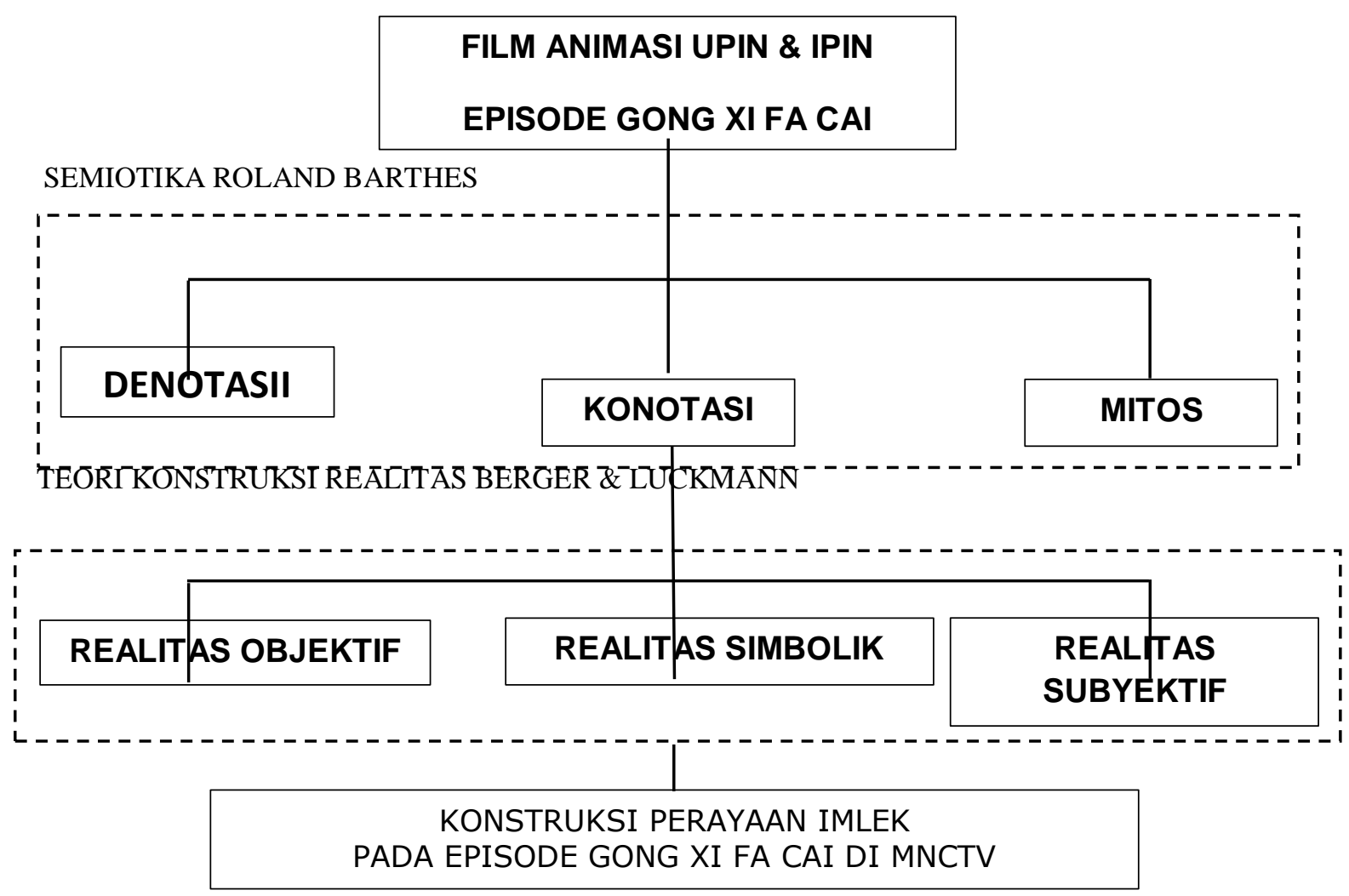

Rd. Dancu lokita Pramesti Dewi et al. (Konstruksi Perayaan Imlek Pada Film Animasi Upin Dan Ipin...) 
Pada tahap ini penulis memilih metode semiotika Roland Barthes sebagai pedoman analisis yang paling tepat. Berbagai pembelajaran konstruksi budaya etnis Tionghoa dalam serial animasi Upin dan Ipin baik itu sifatnya nyata atau tersembunyi. Analisis dilakukan berdasarkan tahap-tahap yang telah ditentukan yaitu tahap denotasi maupun konotasi. Setelah melakukan analisis mitos, maka penulis akan menangkap cerita atau misi dalam film tersebut.

\section{METODE PENELITIAN}

Penelitian ini adalah penelitian kualitatif - konstruktif, berupa analisis Semiotika terhadap Makna Konstruksi Perayaan Imlek dalam serial Upin Dan Ipin dalam Episode Gong Xi Fa Cai di MNCTV. Untuk mencapai titik pemaknaan pesan Perayaan Imlek yang disampaikan dalam film animasi serial Upin dan Ipin dalam episode Gong Xi Fa Cai di MNCTV, maka penelitian ini menggunakan metode Semiotik.

Semiotika atau penyelidikan simbol-simbol, membentuk tradisi pemikiran yang penting dalam teori komunikasi. Tradisi semiotik terdiri atas sekumpulan teori tentang bagaimana tandatanda mempresentasikan benda, ide, keadaan, situasi, perasaan dan kondisi diluar tanda-tanda itu sendiri (Littlejhon dan Foss, 2011:53). Metode semiotika dititikberatkan tidak pada pemusatan transmisi pesan, melainkan kepada peranan komunikasi dalam memantapkan dan memelihara nilainilai dan bagaimana nilai-nilai tersebut memungkinkan proses komunikasi memiliki makna. Untuk mendapatkan deskripsi semiotik, maka data yang didapat dihubungkan dengan proposisi teoritis yang sudah dibangun, diorganisasikan dalam bentuk kerangka semiotik. Kemudian diintreprestasikan. Selanjutnya dilakukan pengecekan ulang baik terhadap data maupun terhadap konsep dan teori. Semiotika dalam penelitian ini sendiri menggunakan pendekatan melalui gagasan signifikasi dua tahap Roland Barthes (Two Order of Signification). Semiotika mengasumsikan pesan medium tersusun atas seperangkat tanda untuk menghasilkan makna tertentu. Makna tersebut bukanlah innate meaning (makna bawaan alamiah), melainkan makna yang dihasilkan oleh sistem perbedaan atau hubungan tanda - tanda. Barthes menciptakan peta tentang bagaimana tanda bekerja (Sobur, 2009:69).

Berikut adalah tabel hubungan tanda, objek dan interpretant (Triangle of Meaning) :

Gambar 3.1. : Triangle of Meaning

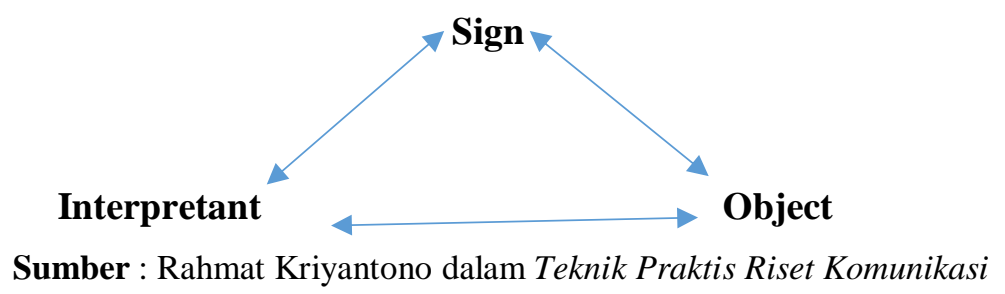

Penelitian dilakukan dengan mengambil adegan-adegan ( yang juga disebut sebagai Scene ) dalam film animasi "Upin dan Ipin " yang menggambarkan Makna Perayaan Imlek pada episode Gong $\mathrm{Xi} \mathrm{Fa} \mathrm{Cai.} \mathrm{Dari} \mathrm{adegan} \mathrm{tersebut} \mathrm{kemudian} \mathrm{dianalisa} \mathrm{dengan} \mathrm{analisa} \mathrm{semiotika} \mathrm{Roland}$ Barthes. Untuk mendapatkan deskripsi semiotik, maka data yang didapat dihubungkan dengan proposisi teoritis yang sudah dibangun, diorganisasikan dalam kerangka semiotik, kemudian diinterprestasikan. Analisis dilakukan per scene yang menunjukkan penggambaran komunikasi antar budaya yang memberikan pembelajaran tentang budi pekerti dan toleransi antar beragama dalam film Upin dan Ipin, kemudian dianalisis mulai dari makna denotasi dan makna konotasi.

\section{HASIL PENELITIAN DAN DISKUSI \\ 4.1 Sejarah dan Makna Hari Raya Imlek Bagi Masyarakat Tionghoa}

Berdasarkan cerita rakyat dan legenda kuno, tahun baru Imlek dirayakan ketika orang Tionghoa berhasil melawan hewan mitos yang disebut sebagai Nian yang berarti tahun dalam 
bahasa Cina. Makhluk Nian selalu muncul pada hari pertama Tahun Baru dan kedatangan Nian adalah memangsa hewan ternak, memakan hasil pertanian dan bahkan penduduk, terutama anakanak. Untuk selamat dari petaka Nian, masyarakat [desa] Tionghoa akan menaruh sejumlah makanan di depan pintu mereka pada hari pertama tahun baru. Masyarakat percaya bahwa, jika Nian telah mengambil atau memakan makanan yang telah disediakan oleh masyarakat, maka Nian tidak akan lagi menyerang orang atau warga. Suatu ketika, seorang penduduk menyaksikan [satu atau seekor makhluk] Nian ketakutan dan lari menghindar dari seorang anak yang berkostum merah.

Dari kejadian itu, maka penduduk desa akhirnya tahu kekurangan Nian yang takut pada warna merah, sehingga mengapa setiap perayaan Imlek masyarakat Tionghoa menggunakan baju berwarna merah. Selain itu, warna merah dalam masyarakat Tionghoa melambangkan keberanian. Semenjak itu, setiap menjelang dan selama Tahun Baru, penduduk akan menggantung lentera merah serta memasang tirai atau gordin merah pada pintu dan jendela. Masyarakat juga menggunakan mercun untuk menakuti Nian. Sejak itulah Nian tidak pernah lagi muncul di desa. Dalam sejarahnya, Nian berhasil ditangkap oleh Hongjun Lao Tze (seorang pendeta Tao), dam kemudian menjadikan Nian sebagai hewan tunggangan Hongjun Lao Tze. Adat-adat pengusiran Nian ini kemudian berkempang menjadi perayaan Tahun Baru. Guò nián (Hanzi tradisional: 過年; bahasa Tionghoa: 过年), yang berarti “menyambut tahun baru”, secara harafiah berarti “mengusir Nian".

Terlepas apakah mitos itu benar atau tidak, yang pasti perayaan Imlek merupakan perayaan yang dilakukan oleh para petani di Cina setelah melewati musim dingin yang menusuk dan mensyukuri permulaan musim baru penuh harapan yakni musim semi yang terjadi setiap tahunnya. Perayaan Imlek dimulai pada tanggal 30 bulan ke-12 dan berakhir pada tanggal 15 bulan pertama (Cap Go Meh). Yang pasti, hari raya Imlek merupakan momen pertemuan seluruh anggota keluarga sekali dalam setahun. Anggota keluarga akan bersilahturahmi, saling berbagi dan memberikan pengalaman selama setahun. Perayaan ini menjadi sangat berarti tatkala setiap anggota keluarga dan tetangga saling menjalin kasih, saling mengayomi, dan memulai lembaran baru (dengan pakaian baru).

\subsection{Penggambaran Konstruksi Realitas Sosial dalam Film Upin dan Ipin Episode Gong Xi Fa Cai}

Segala bentuk realitas sosial termasuk isi media, baik media cetak maupun media elektronik merupakan realitas yang sengaja dikonstruksi. Menurut Berger realitas itu tidak dibentuk secara ilmiah, tidak juga sesuatu yang diturunkan Tuhan. Tetapi sebaliknya, ia dibentuk dan dikonstruksi (Eriyanto, 2012:18). Berger membagi realitas sosial menjadi tiga macam realitas, yaitu realitas obyektif, realitas simbolik dan realitas subyektif.

Berdasarkan tiga macam realitas sosial yang diungkapkan Berger dan Luckmann (Samuel, 2012), terdapat beberapa makna realitas budaya Tionghoa yang dapat diperoleh dalam film animasi Upin dan Ipin dalam episode "Gong Xi Fa Cai" di MNCTV, diantaranya pertama pada sequence 1 dan Scene 1, realitas objective pada scene ini adalah Meimei sebagai pembuka episode "Gong Xi Fa Cai" menggunakan bahasa cina, realitas simboliknya terletak pada baju dan background latar yang bertema Imlek. Bernuansa warna Merah. Terlihat pula Upin, Ipin dan Ehsan turut menggunakan baju cina sebagai bentuk toleransi kepada agama Meimei. Realitas subyektifnya adalah film animasi Upin Ipin sangat menghargai agama lain serta memiliki rasa toleransi yang tinggi terhadap agama lain.

Kedua, sequence 2 dan Scene 1. Realitas objektif pada scene ini adalah Meimei yang merupakan etnis Tionghoa datang ke lapangan tempat biasa mereka bermain yang disana terdapat kawan kawannya Upin, Ipin, Fizi dan Ehsan. Meimei membawa kotak besar berisi limau (jeruk) dan disana juga meimei mengundang kawan-kawannya untuk datang ke rumah meimei pada hari kedua untuk makan besar merayakan hari raya imlek. Realitas subyektif yang ditampilkan adalah 
Meimei ingin mendekatkan diri untuk bersahabat dengan teman-temannya, sedangkan realitas simboliknya adalah ingin memperlihatkan bahwa orang Tionghoa adalah orang yang ramah dan bersahabat. Selain itu, pada scene ini didapatkan realitas obyektif pada Mail, dimana Mail menjual mercon mainan yang menggunakan baterai. Realitas simbolik pada scene ini adalah Mercon sebagai ciri khas imlek yang pasti ada pada saat hari raya cina sedangkan realitas subyektifnya memiliki arti sebagai pengusir segala bentuk kejahatan yang ada, baik itu kejahatan dari dalam diri individu maupun diluar diri individu.

Ketiga, sequence 2 dan scene 2. Realitas objektifnya adalah Uncle Ahtong. yang menjual tulisan-tulisan cina atau biasa disebut Chunlian. Realitas simboliknya adalah Raksasa Nian yang dipercaya pada zaman dahulu suka memakan anak-anak kecil yang keluar pada malam hari. Cerita ini diceritakan oleh uncle Ahtong kepada Upin dan Ipin, karena sebelumnya Upin dan Ipin menanyakan arti kata dari "Ong", yang kemudian Uncle Ahtong menjelaskan latar belakang dari "Ong" dan menjadi realitas simbolik dari episode ini. Sedangkan realitas subyektif dari scene ini adalah tulisan cina Chunlian yang dijual oleh Uncle Ahtong. Yang dipercaya membawa tuah atau berkah bagi yang memiliki tulisan chunlian tersebut.

Keempat, sequence 2 dan scene 3. Realitas obyektif terlihat pada saat Uncle Ahtong yang sedang bermain mercon atau kembang api di halaman depan rumahnya dengan dua anak kecil anak tetangga. Uncle Ahtong hidup sendiri, dia tidak memiliki sanak saudara yang harus dia kunjungi, sedangkan malam itu adalah malam hari raya Imlek. Realitas simbolik pada scene ini adalah kebersamaan berkumpul bersama seluruh keluarga besar yang biasa dilakukan oleh masyarakat Tionghoa pada malam hari raya sebelum Imlek. Realitas subyektif pada scene ini adalah kesedihan uncle Ahtong yang tidak bisa berkumpul bersama sanak saudara seperti keluarga lainnya pada hari raya Imlek.

Kelima, sequence 3 dan scene 1. Realitas obyektif pada scene 1 adalah Opah meminta kedua cucunya untuk hadir berkunjung kerumah uncle ahtong pada saat perayaan hari raya Imlek, karena Uncle Ahtong tidak memiliki saudara atau tinggal sendirian saja. Realitas Simbolik pada scene ini adalah perayaan Imlek ditandai dengan kumpul bersama seluruh keluarga besar. Dan Realitas Subyektifnya Opah menginginkan kedua cucunya Upin dan Ipin menjadi manusia yang selalu bisa menghormati dan menghargai orang lain, baik itu yang sesuku ataupun yang berbeda suku atau ras.

Keenam, sequence 3 dan scene 2. Realitas objektif pada scene ini adalah Upin dan Ipin yang banyak menerima amplop angpau berisi uang dari pemberian Uncle Ahtong, karena datang mengucapkan selamat hari raya Imlek ke rumah Uncle Ahtong. Realitas simboliknya adalah amplop angpao. Angpao merupakan tradisi yang dilakukan oleh masyarakat Tionghoa dalam merayakan hari raya Imlek. Angpao diberikan kepada orang yang tidak mampu atau fakir miskin, kepada anakanak kecil dan remaja yang masih lajang atau belum menikah. Realitas subyektif pada scene ini makna angpao yang diberikan kepada orang yang membutuhkan, bahwa menurut tradisi masyarakat cina dengan memberikan sebagian rezeki kepada orang lain maka secara tidak langsung akan menambah rezeki mereka di tahun kedepannya.

Ketujuh, sequence 3 dan scene 3. Realitas obyektif pada scene ini adalah Baju Cina yang akan dikenakan oleh Ehsan. Pada scene ini, terlihat Ehsan menelephone Upin dan Ipin untuk memberitahukan bahwa dia baru saja dibelikan baju cina berwarna emas oleh ayahnya. Realitas simboliknya adalah Baju Cina identik dengan warna merah dan warna emas yang suka dipakai dihari raya Imlek. Realitas suyektifnya, Ehsan ingin agar kawannya Upin dan Ipin mengetahui bahwa dia akan mengenakan pakaian cina yang baru dibeli oleh orangtuanya.

Kedelapan, sequence 4 dan scene 1. Realitas obyektif dari scene ini adalah kegembiraan Meimei dikarenakan kawan-kawannya hadir dihari kedua Imlek. Meimei sangat gembira karena semua kawan-kawannya serta warga kampung "Durian Runtuh" dapat hadir kerumah Meimei untuk berkunjung dan mengucapkan selamat hari raya Imlek. Hal ini terlihat dalam perkataan Meimei kepada kawan-kawannya "Wah... Kamu semua datang...saya suka..saya suka”. Realitas simbolik pada scene ini adalah tradisi orang Tionghoa pada saat hari raya Imlek adalah berkunjung atau

Rd. Dancu lokita Pramesti Dewi et al. (Konstruksi Perayaan Imlek Pada Film Animasi Upin Dan Ipin ...) 
dikunjungi sanak saudara, orang tua, teman-teman atau kerabat dekat yang tujuannya untuk lebih mempererat tali persaudaraan. Realitas subyektifnya adalah masyarakat etnis Tionghoa sangat menyenangi kedamaian dan kesejahteraan.

Kesembilan, sequence 4 dan scene 2,3,4,5. Pada scene 2, realitas obyektif adalah ketika Meimei dan keluarganya menyewa barongsai atau tarian singa untuk datang kerumah Meimei pada saat perayaan Imlek. Realitas simboliknya, barongsai atau tarian singa merupakan simbol kebahagiaan, kegembiraan dan kesejahteraan bagi masyarakat etnis Tionghoa. Sedangkan realitas subyektifnya adalah barongsai biasanya ada pada saat perayan hari raya Imlek, pesta dan lainnya. Pada scene 3 dan 4, realitas objektif yang didapat adalah ketika buah limau (jeruk) yang dipegang Ipin diambil oleh salah satu barongsai yang sedang aksi dirumah meimei. Barongsai mengupas limau (jeruk) tersebut dan dikembalikan kepada Ipin. Pada scene ini terlihat Ipin sempat tertegun bingung mengapa hal tersebut dilakukan oleh barongsai, dan apakah limau (jeruk) tadi masih bisa dimakan atau tidak. Pada saat ini, Meimei mangatakan bahwa hal tersebut adalah "Ong" artinya banyak unsur keberuntungan didalamnya. Hal ini terlihat dalam dialognya "Boleh dimakan.... Banyak Ong! Tak mau...bagi saya". Realitas simboliknya adalah buah bagi masyarakat etnis Tionghoa merupakan anugerah dari tuhan yang diberiakan di alam yang kemudian digunakan dan bisa dimakan oleh manusia, sehingga buah bisa digunakan untuk melakukan sesajen atau persembahan kepada para leluhur yang sudah meninggal sebagai bentuk tanda syukur. Dan realitas subyektifnya adalah masyarakat etnis Tionghoa sangat percaya apa yang didapat dari Tuhan melewati alam semesta dan segala isinya harus dipelihara, dijaga dan dipergunakan sebagaimana mestinya dengan baik dan benar.

Selanjutnya, pada scene 5 dalam sequence 4, realitas obyektifnya adalah daun yang jatuh karena dimakan oleh barongsai tidak boleh disapu atau dibersihkan. Hal ini ditandai oleh pertanyaan Ipin pada scene "Tak ape... sepah ni nanti di sapu kan Meimei?" dan kemudian Meimei menjawab "Tak boleh... ini semua Ong !". Realitas simboliknya adalah masyarakat etnis Tionghoa percaya bahwa daun yang berguguran jatuh ke tanah merupakan rezeki yang tidak akan habishabisnya atau akan terus mengalir setiap tahun bagi mereka. Pada scene 6, realitas objektifnya adalah Mercon yang tidak meletus semuanya sampai habis. Hal ini ditandai dalam percakapan Jarjit dan Meimei. Jarjit bertanya "Haaa Tidak Habis?", kemudian Meimei menjawab "Hayaaa... Nasib baik semua mercon habis, tidak ada Ong!". Realitas simbolik pada scene ini bahwa masyarakat etnis Tionghoa percaya mercon yang dibakar hingga habis menandakan keburukan yang ada didalam diri manusia, baik itu didalam tubuh maupun diluar tubuh, akan ikut terbuang dan akan berganti menjadi manusia yang lebih bersih atau baik. Sedangkan realitas subyektifnya adalah Mercon yang dinyalakan juga melambangkan rasa bahagia dan rasa syukur telah melewati tahun lalu dengan sukses.

\subsection{Konstruksi Perayaan Imlek Pada Film Animasi Upin dan Ipin dalam Episode Gong Xi Fa Cai di MNCTV}

Konstruksi yang dibangun dalam cerita Upin dan Ipin episode Gong Xi Fa Cai memperlihatkan bahwa perayaan Imlek merupakan perayaan masyarakat Tionghoa. Imlek telah menjadi hari besar bagi seluruh masyarakat Tionghoa dimanapun berada. Tidak terkecuali apapun agamanya. Selama individu masih mengaku dirinya orang Tionghoa maka akan merayakan hari Imlek. Bangsa Tionghoa dikenal sebagai bangsa yang punya akar budaya yang sangat kuat, dimanapun berada biasanya tidak lupa untuk tetap merayakan tahun baru Imlek atau "Chinese New Year". Walaupun Imlek adalah perayaan agama, namun perayaan Imlek telah menjadi tradisi dalam masyarakat Tionghoa, karena Imlek memiliki makna filosofi yang terkandung dibalik tradisinya. Mulai dari semangat dan kesanggupan berbagi dengan sesama, saling membantu satu sama lainnya, cinta damai tidak menyukai perang atau perselisihan.Perayaan imlek adalah perayaan tahun baru, waktunya bersyukur terhadap rezeki yang diberikan Tuhan ditahun lalu serta semangat untuk tahun yang lebih baik di tahun tahun kedepannya. Bermaaf-maafan dengan anggota keluarga, orang yang 
lebih tua menyayangi orang muda dalam bentuk memberi angpao, orang muda menyayangi orang yang lebih tua dalam bentuk bakti.

Sebagian besar orang menganggap hari besar Imlek hanyalah sebuah tradisi yang turun temurun untuk merayakan pergantian tahun baru. Sedangkan sebagian orang lainnya mengganggap hari besar Imlek sebagai hari raya agama yang sarat akan makna ritual agama didalamnya, seperti melakukan sembahyang kepada para leluhur, dewa dan dewi, Thian dan lain sebagainya. Semuanya tidak terlepas dari unsur ritual yang mendalam. Bagi masyarakat yang menganggap Imlek sebagai hari raya tradisi hanya melakukan kegiatan seremoni saja, seperti makan malam bersama, berkumpul dengan seluruh keluarga, saling mengucapkan Gong Xi Fa Cai, dan berbagi angpao. Ritual lainnya yang biasa dilakukan pada saat Imlek adalah memakai pakaian serba merah atau berwarna emas. Hal ini dilakukan dengan tujuan agar selalu mendapatkan perlindungan, keberanian, kesejahteraan, kesuksesan dan kebahagiaan untuk menjalani kehidupan ditahun depan.

\section{SIMPULAN}

Media televisi pada dasarnya merupakan arena symbol atau tanda-tanda. Tanda sebagai sistem bahasa dalam teks televisi dapat dimaknai dengan menggunakan metode semiotika. Dengan pendekatan analisis semiotika Roland Barthes dan Teori Konstruksi Realitas Sosial Berger dan Luckmann terhadap perayaan imlek pada film animasi Upin dan Ipin dalam episode "Gong $\mathrm{Xi} \mathrm{Fa}$ Cai" di MNCTV, terlihat film ini menjelaskan perayaan imlek yang biasa dilakukan masyarakat etnis Tionghoa pada saat hari raya Imlek. Hasil penelitian menghasilkan dua kesimpulan, yaitu pertama konstruksi yang dibangun dalam cerita Upin dan Ipin episode "Gong Xi $\mathrm{Fa} C a i$ " memperlihatkan bahwa perayaan Imlek merupakan perayaan masyarakat Tionghoa. Imlek telah menjadi hari besar bagi seluruh masyarakat Tionghoa dimanapun berada, tidak terkecuali apapun agamanya, karena Imlek bukan lagi telah dianggap sebagai tradisi budaya Tionghoa. Selama mengaku sebagai orang Tionghoa maka akan merayakan hari raya Imlek, dan menjadikan bangsa Tionghoa mempunyai akar budaya kuat.

Film animasi Upin dan Ipin dalam episode "Gong Xi Fa Cai", menjadikan makna perayaan imlek sebagai perayaan spiritual dan menjadi penyatu dalam semangat hidup yang sama. Makna spiritual perayaan imlek tidak semata-mata digali dalam ajaran agama tertentu. Imlek memiliki makna filosofi yang terkandung dibalik tradisinya. Mulai dari semangat dan kesanggupan berbagi dengan sesama, saling membantu satu sama lain, cinta damai, tidak menyukai perang atau perselisihan. Pemberian angpao merupakan bentuk simbolik dari rasa berbagi dan menolong antar sesama manusia atau makhluk hidup yang diciptakan oleh Tuhan, dan menjadi simbol berbagi kesejahteraan dari para orang tua kepada anak-anaknya, membagi kepada orang yang tidak mampu atau miskin. Dengan semangat berbagi ini, setiap orang dapat merayakan imlek, karena semangat berbagi tidak hanya ada di kalangan sesama etnis saja tetapi bagi seluruh umat manusia atau makhluk hidup.

\section{DAFTAR PUSTAKA}

Eriyanto. (2011). “Analisis Framing”: Konstruksi Ideologi, dan Politik Media. Yogyakarta: Lkis. Littlejohn. (2011). Theories Of Human Communication " 6th Editon. New Mexico: : Wadsworth Publishing Company

Morissan. (2009). Teori Komunikasi, Individu hingga Massa, Jakarta : Kencana Prenada Group. Samuel, Hanneman. (2012). Peter Berger Sebuah Pengantar Ringkas. Jawa Barat: Kepik.

Sobur, Alex. (2009). Analisis Teks media. Bandung : Remaja Rosda Karya.

Ramadhani, Dyah Ayu Rizky Kusuma. (2018). Emosi Dasar dalam Film (Studi Analisa Semiotika dalam Film Animasi Inside Out. Undergraduate (S1) Thesis Universitas Muhammadiyah Surakarta. 